\title{
Peningkatan Pemahaman Mahasiswa dalam Perkuliahan Diagnostik Kesulitan Belajar Melalui Pengajaran Tutorial
}

\author{
Yulidar Ibrahim \\ Universitas Negeri Padang \\ ఏ e-mail: yulidar@konselor.org
}

\begin{abstract}
Each of students appealingly is entitled to gain a chance to achieve a satisfactory academic performance. In other words, s/he has the same opportunity to gain satisfactory learning outcomes. As the matter of fact, every student has various differences both in terms of intellectual abilities, talents, interests, willingness, attention, participation, family background, attitudes, and study habits that sometimes very conspicuous between one to another. Consequently, they receive diversity in satisfactory learning outcomes. This study aims to illustrate the improvement of students' understanding in diagnostic lectures of learning difficulties through tutorial teaching using method of Classroom Action Research (PTK). The subjects of the study were students enrolled in one of the difficulty diagnostic lecture sessions during semester of January - June 2016 amounted to 37 people. This research used observation format as research instrument through tutorial activity, diagnostic PTK diagnostic instrument and answer sheet. Data was analysed applying descriptive statistical techniques, whereas the analysis of diagnostic PTK instruments of learning difficulties based on scores obtained by the students and described in tabulation. The results of this study revealed that there is an improvement in student understanding in diagnostic lecture of learning difficulties through tutorial teaching.
\end{abstract}

Keyword: student, diagnostic of learning difficulty, tutorial teaching

Copyright (C) 2017 IICET (Indonesia) - All Rights Reserved

Indonesian Institute for Counseling, Education and Therapy (IICET)

\section{PENDAHULUAN}

Mata kuliah Diagnosis kesulitan belajar merupakan salah satu mata kuliah wajib yang harus diikuti oleh seluruh mahasiswa jurusan Bimbingan dan Konseling. Mata kuliah ini termasuk kelompok Mata Kuliah Bidang Studi (MKBS). Mata kuliah ini bertujuan untuk menambah wawasan, kemampuan, keterampilan, nilai dan sikap profesi Bimbingan dan Konseling. Secara jelas deskripsi mata kuliah diagnosis kesulitan belajar meliputi; hakekat, latar belakang dan kedudukan, pengertian, tujuan, fungsi, prosedur, model pendekatan, teknik pelaksanaan serta langkah-langkah pelaksanaan diagnosis kesulitan belajar, program perbaikan/pengayaan.

Pada dasarnya mata kuliah ini disajikan dengan memadukan antara teori dan praktek yang diatur dalam setiap pertemuan perkuliahan mingguan. Disamping itu mahasiswa menguasai konsep-konsep diagnosis kesulitan belajar secara umum, mahasiswa juga diarahkan untuk mengunakan konsep diagnosis kesulitan belajar dalam praktek diagnosis kesulitan belajar di sekolah latihan dan juga memberikan pelayanan Bimbingan dan Konseling.

Setiap tahun peneliti melaksanakan perkuliahan diagnostik kesulitan belajar dengan menggunakan metode ceramah, diskusi, tanya jawab dan pembahasan, dan pengentasan kasus-kasus yang ditemui di tempat 
sekolah latihan pada setiap minggu pertemuan. Walaupun pelaksanakan perkuliahan sudah di laksanakan dengan berbagai metode dan pendekatan, hasilnya belum sesuai dengan harapan,hal ini terlihat dengan setiap tahun ada saja mahasiswa yang tidak lulus, kualitas tugas dan waktu penyerahan tidak sesuai dengan jadwal yang sudah di tetapkan, mutu tugas yang sangat rendah, serta kemampuan menganalisis dan mengentaskan kasus-kasus yang ditemui rendah.

Keberhasilan dalam menyelesai-kan pendidikan dapat dilihat dari prestasi belajarnya, prestasi belajar merupakan suatu tolak ukur tentang hasil pendidikan dalam sekolah, peningkatan prestasi belajar itu dapat memberikan informasi mengenai kualitas pendidikan termasuk pengelolaan pembelajaran (Ni Putu Sri Nonik Andayani, dkk, 2014). Pada prinsipnya setiap pelajar memiliki hak memperoleh peluang untuk mencapai kinerja akademik yang memuaskan. Namun, dalam realita sehari-hari setiap pelajar memiliki berbagai perbedaan, baik dalam hal kemampuan intelektual, bakat, minat, kemauan, perhatian, partisipasi, latar belakang keluarga, sikap, dan kebiasaan belajar yang terkadang sangat mencolok antara yang satu dengan lainnya (Zainal Abidin, 2006; Bear, 2012).

Anggina Pratiwi Haryatni (2014) faktor psikologi merupakan salah satu faktor yang menyebabkan kesulitan belajar yang meliputi intelegensi, perhatian dan kesiapan, dan semangat berada pada sebagian besar yaitu sebesar $61.16 \%$. Maksudnya bahwa banyak yang mengalami kesulitan belajar dikarenakan faktor psikologi, seperti intelegensi yang rendah, kurangnya perhatian saat jam pelajaran berlangsung, kurang siap dan semangat dalam menerima pelajaran. Selain itu, faktor emosi dan kebiasaan yang salah yang meliputi malas belajar, kurang berminat, sering bolos dan aktivitas yang kurang menunjang berada pada "sebagian besar" yaitu 55,73. Hal ini tampak pada kebiasaan malas-malasan saat belajar, kurang berminat dalam belajar, dan sering bolos saat jam pelajaran belajar.

Aktivitas belajar bagi setiap individu, tidak selamanya dapat berlangsung secara wajar. Perbedaan individual anak didik merupakan faktor yang akan menentukan proses belajar. Secara umum apabila seseorang dapat mengikuti pelajaran dengan baik tanpa adanya gangguan, perbedaan individu tersebut tidak akan nampak secara signifikan.

Masalah-masalah tersebut perlu dicarikan pemecahannya sehingga kualitas pembelajaran dan peningkatan penguasaan mahasiswa dapat meningkat. Hal ini sejalan dengan yang dijelaskan oleh Zainal Abidin (2006) bahwasanya diperlukan langkah positif untuk mengentaskan kesulitan belajar yang biasa dialami, sekaligus untuk mendukung lajunya kualitas proses belajar-mengajar untuk meningkatkan prestasi seoptimal mungkin (Ahmad, Al-mashari, \& Al-lawati, 2010). Salah satu strategi yang dilaksanakan adalah dengan pengajaran tutorial, yaitu mahasiswa yang sudah menguasai konsep pembelajaran diagnosis kesulitan belajar pada setiap pertemuan diharuskan membimbing mahasiswa yang belum menguasai dengan cara dosen memberikan bantuan dengan mengarahkan mahasiswa untuk mengentaskan kasus-kasusnya. Mata kuliah Diagnosis kesulitan belajar merupakan salah satu mata kuliah wajib yang harus diikuti oleh seluruh mahasiswa jurusan Bimbingan dan Konseling. Mata kuliah ini termasuk kelompok Mata Kuliah Bidang Studi (MKBS). Mata kuliah ini bertujuan untuk menambah wawasan, kemampuan, keterampilan, nilai dan sikap profesi Bimbingan dan Konseling. Secara jelas deskripsi mata kuliah diagnosis kesulitan belajar meliputi; hakekat, latar belakang dan kedudukan, pengertian, tujuan, fungsi, prosedur, model pendekatan, teknik pelaksanaan serta langkah-langkah pelaksanaan diagnosis kesulitan belajar, program perbaikan/pengayaan.

Pada dasarnya mata kuliah ini disajikan dengan memadukan antara teori dan praktek yang diatur dalam setiap pertemuan perkuliahan mingguan. Disamping itu mahasiswa menguasai konsep-konsep diagnosis kesulitan belajar secara umum, mahasiswa juga diarahkan untuk mengunakan konsep diagnosis kesulitan belajar dalam praktek diagnosis kesulitan belajar di sekolah latihan dan juga memberikan pelayanan Bimbingan dan Konseling.

Setiap tahun peneliti melaksanakan perkuliahan diagnostik kesulitan belajar dengan menggunakan metode ceramah, diskusi, tanya jawab dan pembahasan, dan pengentasan kasus-kasus yang ditemui di tempat sekolah latihan pada setiap minggu pertemuan. Walaupun pelaksanakan perkuliahan sudah di laksanakan dengan berbagai metode dan pendekatan, hasilnya belum sesuai dengan harapan,hal ini terlihat dengan setiap tahun ada saja mahasiswa yang tidak lulus, kualitas tugas dan waktu penyerahan tidak sesuai dengan jadwal yang sudah di tetapkan, mutu tugas yang sangat rendah, serta kemampuan menganalisis dan mengentaskan kasus-kasus yang ditemui rendah. 
Keberhasilan dalam menyelesai-kan pendidikan dapat dilihat dari prestasi belajarnya, prestasi belajar merupakan suatu tolak ukur tentang hasil pendidikan dalam sekolah, peningkatan prestasi belajar itu dapat memberikan informasi mengenai kualitas pendidikan termasuk pengelolaan pembelajaran (Ni Putu Sri Nonik Andayani, dkk, 2014). Pada prinsipnya setiap pelajar memiliki hak memperoleh peluang untuk mencapai kinerja akademik yang memuaskan. Namun, dalam realita sehari-hari setiap pelajar memiliki berbagai perbedaan, baik dalam hal kemampuan intelektual, bakat, minat, kemauan, perhatian, partisipasi, latar belakang keluarga, sikap, dan kebiasaan belajar yang terkadang sangat mencolok antara yang satu dengan lainnya (Zainal Abidin, 2006; Bear, 2012).

Anggina Pratiwi Haryatni (2014) faktor psikologi merupakan salah satu faktor yang menyebabkan kesulitan belajar yang meliputi intelegensi, perhatian dan kesiapan, dan semangat berada pada sebagian besar yaitu sebesar $61.16 \%$. Maksudnya bahwa banyak yang mengalami kesulitan belajar dikarenakan faktor psikologi, seperti intelegensi yang rendah, kurangnya perhatian saat jam pelajaran berlangsung, kurang siap dan semangat dalam menerima pelajaran. Selain itu, faktor emosi dan kebiasaan yang salah yang meliputi malas belajar, kurang berminat, sering bolos dan aktivitas yang kurang menunjang berada pada "sebagian besar" yaitu 55,73. Hal ini tampak pada kebiasaan malas-malasan saat belajar, kurang berminat dalam belajar, dan sering bolos saat jam pelajaran belajar.

Aktivitas belajar bagi setiap individu, tidak selamanya dapat berlangsung secara wajar. Perbedaan individual anak didik merupakan faktor yang akan menentukan proses belajar. Secara umum apabila seseorang dapat mengikuti pelajaran dengan baik tanpa adanya gangguan, perbedaan individu tersebut tidak akan nampak secara signifikan.

Masalah-masalah tersebut perlu dicarikan pemecahannya sehingga kualitas pembelajaran dan peningkatan penguasaan mahasiswa dapat meningkat. Hal ini sejalan dengan yang dijelaskan oleh Zainal Abidin (2006) bahwasanya diperlukan langkah positif untuk mengentaskan kesulitan belajar yang biasa dialami, sekaligus untuk mendukung lajunya kualitas proses belajar-mengajar untuk meningkatkan prestasi seoptimal mungkin (Ahmad, Al-mashari, \& Al-lawati, 2010). Salah satu strategi yang dilaksanakan adalah dengan pengajaran tutorial, yaitu mahasiswa yang sudah menguasai konsep pembelajaran diagnosis kesulitan belajar pada setiap pertemuan diharuskan membimbing mahasiswa yang belum menguasai dengan cara dosen memberikan bantuan dengan mengarahkan mahasiswa untuk mengentaskan kasus-kasusnya.

\section{METODOLOGI}

Penelitian ini dilakukan dalam perkuliahan diagnosis kesulitan belajar selama satu semester pada semester Januari - Juni 2016 dengan jumlah subjek penelitian sebanyak 37 orang. Instrumen yang digunakan dalam penelitian ini adalah format observasi kegiatan tutorial, instrumen PTK diagnostik kesulitan belajar dan Lembaran jawaban. Penelitian ini adalah Penelitian Tindakan Kelas (PTK). PTK merupakan salah satu upaya untuk peningkatan kualitas pendidikan.

Peningkatan kualitas pendidikan di Indonesia merupakan upaya yang tidak dapat di tawar-tawar lagi karena problema pendidikan semakin rumit. Untuk itu, penanganan masalah pendidikan merupakan upaya yang harus dilakukan bersama pemerintah, masyarakat dan orang tua peserta didik (Nurhijrah,2001).

Berdasarkan pengalaman peneliti sebagai dosen diagnosis kesulitan belajar pada setiap tahun mengungkapkan bahwa tingkat penguasaan mahasiswa dalam pembelajaran diagnosis kesulitan belajar masih tergolong rendah, terutama dalam bentuk kerja sama dalam melakukan praktek diagnostik di sekolah latihan kurang terlihat, mereka lebih banyak melaksanakan secara individual. Di sisi lain mahasiswa merasa kesulitan dalam mengentaskan masalah yang berkaitan dengan kesulitan belajar yang dialami oleh siswa di sekolah latihan. Salah satu usaha yang dapat dilakukan untuk meningkatkan tingkat penguasaan dapat dilakukan dengan Penelitian Tindakan Kelas (PTK).

Penelitian Tindakan Kelas (PTK) menurut Mc Niff (dalam Suharsimi 2006) sebagai bentuk pengembangan inovasi reflektif yang dilakukan oleh pendidik sendiri terhadap kurikulum pengembangan sekolah, meningkatkan prestasi belajar, pengembangan keahlian mengajar dan sebagainya. Lebih lanjut Suharsimi (2006) menjelaskan PenelitianTindakan Kelas (PTK) merupakan tiga kata Pengembangan Inovasi + Tindakan + Kelas, hal ini dijelaskan dalam uraian berikut; (1) pengembangan inovasi adalah kegiatan 
mencermati suatu objek, menggunakan aturan metodologi tertentu untuk memperoleh data atau informasi yang bermanfaat untuk meningkatkan mutu suatu hal yang menarik minat dan penting bagi peneliti, (2) tindakan adalah sesuatu gerak kegiatan yang sengaja dilakukan dengan tujuan tertentu, yang dalam pengembangan inovasi berbentuk rangkaian siklus kegiatan, (3) kelas adalah sekelompok peserta didik dalam waktu yang sama menerima pelajaran yang sama dari seorang guru.

Dengan demikian Penelitian Tindakan Kelas (PTK) bukanlah sekadar mengajar seperti biasanya tetapi harus mengandung satu pengertian bahwa tindakan yang dilakukan didasarkan atas upaya meniningkatkan hasil, yaitu lebih baik dari sebelumnya. Ide dicobakan dalam Penelitian Tindakan Kelas (PTK) harus cemerlang dan guru yakin hasilnya akan lebih baik.

Usaha lain yang dapat dilakukan dalam meningkatkan kualitas pendidikan adalah layanan pembelajaran. Layanan pembelajaran adalah layanan yang di berikan guru kepada peserta didik agar peserta didik dapat meningkat tingkat penguasaannya, layanan yang di berikan bukan layanan yang hanya sesuai dengan tuntutan kurikulum saja, melainkan layanan yang diberikan sesuai dengan kebutuhan peserta didik. Menurut Prayitno (1997) layanan pembelajaran adalah salah satu pelayanan yang dapat membantu siswa/mahasiswa dalam mengembangkan diri, sikap dan kebiasaan belajar yang baik untuk menguasai pengetahuan keterampilan serta menyiapkannya untuk melanjutkan pendidikan pada tingkat tinggi.

Fungsi utama layanan pembelajaran adalah pemeliharaan pengembangan peserta didik, sedangkan secara umum layanan pembelajaran meliputi pengenalan peserta didik yang mengalami masalah belajar diantaranya kemampuan, motivasi, sikap dan kebiasaan belajar yang baik, pengembangan keterampilan belajar diantaranya membaca, mencatat, bertanya dan menjawab, dan menulis, pengajaran perbaikan dan pengajaran pengayaan. Menurut Prayitno (1997) layanan pembelajaran dapat dilakukan sebagai berikut; (1) peningkatan motivasi belajar, (2) peningkatan keterampilan belajar, (3) pengembagan sikap dan kebiasaan belajar, (4) pengajaran perbaikan, (5) program pengayaan, (6) pengembangan dan pemanfaatan lingkungan sekitar.

Peningkatan kualitas pendidikan dapat juga dilakukan dengan pembelajaran tutorial. Pembelajaran merupakan istilah yang hampir sama dengan istilah pengajaran. Pengajaran merupakan kegiatan yang dilaksanakan oleh guru terhadap siswa yang bertujuan agar siswa mendapat penambahan pengetahuan dan keterampilan. Menurut Muhibbin Syah (1995) konsep mengajar mengacu kepada 3 (tiga) konsep yaitu pengertian kuantitatif, pengertian institusional dan pengertian kualitatif. Pengertian kuantitatif menyangkut penambahan pengetahuan yang diperoleh oleh siswa, sedangkan pengertian institusional adalah menyangkut kelembagaan atau sekolah secara keseluruhan. Pengertian kualitatif berhubungan dengan "the facilitation of learning" yaitu membantu dan memudahkan kegiatan belajar siswa. Dalam hal ini guru berinteraksi dengan siswa sehingga siswa terlibat dalam kegiatan belajar sepenuhnya.

Keterlibatan siswa secara aktif merupakan konsep pembelajaran. Dalam kegiatan pembelajaran diharapkan siswa tidak hanya terlibat dalam aktivitas belajar di kelas dengan guru, tetapi timbul keinginan siswa untuk melanjutkan kegiatan di luar kelas untuk mendalami dan membahas materi yang diajarkan di kelas. Rochman Natawijaya dan Moein Moesa (1992) mengemukakan bahwa pembelajaran adalah upaya pembimbingan terhadap siswa agar siswa secara sadar dan terarah berkeinginan untuk belajar dan memperoleh hasil belajar sebaik-baiknya, sesuai dengan keadaan dan kemampuan siswa yang bersangkutan. Pengajaran diawali dengan membuat perencanaan belajar, pelaksanaan kegiatan belajar dan melakukan evaluasi terhadap perencanaan belajar yang dilakukan.

Menurut Agus salim (2004) diantara peran dan fungsi guru adalah sebagai perancang desain pembelajaran dan pengelola proses pembelajaran. Dikemukakan pula bahwa proses pembelajaran seharusnya mampu memicu optimalisasi fungsi otak, emosional dan otak intelektual sehingga tercipta multiple change of education. Adanya hubungan serasi antara otak emosional dan otak intelektual yang memungkinkan seseorang dapat berpikir dan mampu mengelola diri dalam belajar. Selanjutnya pembelajaran yang telah dirancang guru dengan pengelolaan proses pembelajaran. Diharapkan proses pembelajaran yang telah dikelola guru akan mendorong siswa untuk belajar sendiri sehingg terbinanya apa yang disebut dengan construction habits of mind.

Kegiatan pembelajaran diarahkan pada tugas-tugas tertentu, untuk melihat tercapainya tujuan yang telah ditetapkan oleh guru perlu melakukan kegiatan evaluasi. Menurut Muhibbin Syah (1995) evaluasi proses 
pembelajaran memiliki beberapa tujuan, yaitu untuk mengetahui tingkat kemajuan yang telah dicapai siswa, untuk mengetahui posisi atau kedudukan individu diantara kelompoknya, untuk mengetahui tingkat usaha yang telah dilakukan siswa dalam belajar, untuk mengetahui sejauh mana siswa telah mendayagunakan kapasi-tasnya dan untuk mengetahui tingkat daya guna dan hasil guna metode mengajar yang telah dilaksanakan oleh guru dalam proses pembelajaran. Berdasarkan hasil evaluasi dapat diketahui hasil dan hal yang menyangkut pembelajaran yang telah dilaksanakan. Untuk mengetahui apakah tujuan sudah tercapai dapat dilaksana-kan dengan pengajaran tutorial.

Tutorial merupakan pengajaran yang lebih bersifat individual, di mana pengajaran ini dapat diselenggarakan dengan memanfaatkan teman sebaya (mahasiswa) yang telahmenguasai materi pembelajaran atau topik-topik yang telah dibahas oleh guru/dosen. DEPDIKBUD (1983) mengemukakan tutor teman sebaya adalah suatu metode yang digunakan seseorang atau beberapa orang mahasiswa yang ditunjuk dan ditugaskan untuk membantu temannya dalam belajar. Sedangkan menurut Prayitno (2004) yang menjadi sasaran dalam kegiatan tutorial adalah pengentasan kesulitan belajar yang dialami mahasiswa. Penyelenggaraan tutorial dapat berupa re-teaching, pelatihan, penugasan, diskusi dan kegiatan kelompok (Khiat, 2015). Pelaksanaan tutor teman sebaya ditunjuk oleh guru/dosen dengan memperhatikan penguasaan dan kemampuan siswa/mahasiswa dalam berkomunikasi dengan temannya. Dengan demikian siswa/mahasiswa yang menjadi tutor memiliki prestasi yang baik dan punya hubungan sosial yang baik dan disenangi diantara sesama siswa/maha-siswa. Adapun keuntungan metode tutorial teman sebaya adalah; a) lebih efisien karena dalam satu termen banyak dapat dibantu dan terbantu, b) terciptanya hubungan yang lebih dekat dan akrab diantara sesama siswa/-mahasiswa, c) diperoleh kesempatan bagi tutor untuk pengayaan dalam belajar sebagai dampak ia membantu temannya, dapat meningkatkan rasa tanggung jawab dan rasa percaya diri.

\section{HASIL DAN PEMBAHASAN}

Hasil Penelitian Tindakan Kelas dilakukan dengan penilaian proses, yaitu setiap kegiatan tutorial yang dilaksana-kan akan dilakukan penilaian langsung, apabila terdapat mahasiswa yang mengalami kesulitan dalam membantu siswa untuk memecahkan masalahakan langsung dibantu oleh kelompoknya di bawah bimbingan dosen. Apabila mahasiswa telah berhasil memahami dan memecahkan masalah siswa berarti kegiatan mahasiswa dilanjutkan sampai akhir semester. Pada akhir semester instrumen PTK di laksanakan lagi untuk melihat apakah mahasiswa betul-betul dapat memahami teori dan pelaksanaan bantuan kesulitan belajar siswa. Data dianalisis melalui teknik statistik deskriptif, sedangkan analisis instrumen PTK diagnosik kesulitan belajar berdasarkan skor yang diperoleh oleh mahasiswa dan digambarkan dalam tabulasi.Berikut ini akan digambarkan hasil instrumen PTK.

Tabel 1. Pemahaman Mahasiswa tentang Tugas Perkembangan Siswa Sekolah Dasar Kelas Rendah

\begin{tabular}{llcccc}
\hline No & \multicolumn{1}{c}{ Item } & $\begin{array}{c}\text { Skor sebelum } \\
\text { kegiatan tutorial }\end{array}$ & $\%$ & $\begin{array}{c}\text { Skor setelah } \\
\text { kegiatan tutorial }\end{array}$ & $\%$ \\
\hline 1 & Perkembangan fisik & 87 & 60.41 & 114 & 79.16 \\
2 & Perkembangan emosi & 118 & 81.94 & 121 & 84.02 \\
3 & Perkembangan mental & 103 & 71.52 & 118 & 81.94 \\
& Rata-rata & 102.66 & 71.29 & 117.67 & 81.71 \\
\hline
\end{tabular}

Tabel 2. Pemahaman Mahasiswa tentang Tugas Perkembangan Siswa Sekolah Dasar Kelas tinggi

\begin{tabular}{llcccc}
\hline No & \multicolumn{1}{c}{ Item } & $\begin{array}{c}\text { Skor sebelum } \\
\text { kegiatan tutorial }\end{array}$ & $\%$ & $\begin{array}{c}\text { Skor setelah } \\
\text { kegiatan tutorial }\end{array}$ & $\%$ \\
\hline 1 & $\begin{array}{l}\text { Menyusun kegiatan yang dapat } \\
\text { melibatkan murid }\end{array}$ & 95 & 65.97 & 125 & 84.46 \\
2 & $\begin{array}{l}\text { Membagi tugas dengan urutan } \\
\text { kerja yang jelas } \\
3\end{array}$ & 107 & 74.30 & 123 & 83.11 \\
Memiliki catatan khusus tentang & 118 & 81.94 & 131 & 88.51 \\
\hline
\end{tabular}




\begin{tabular}{|c|c|c|c|c|c|}
\hline & perkembangan murid & & & & \\
\hline 4 & $\begin{array}{l}\text { Memberikan perhatian khusus } \\
\text { pada murid yang bingung dalam } \\
\text { membuat tugas }\end{array}$ & 129 & 89.58 & 138 & 93.24 \\
\hline 5 & $\begin{array}{l}\text { Membuat proses pembelajaran } \\
\text { lebih mnyenangkan }\end{array}$ & 110 & 76.38 & 126 & 85.14 \\
\hline 6 & $\begin{array}{l}\text { Mengupayakan peningkatan } \\
\text { potensi murid }\end{array}$ & 114 & 79.16 & 128 & 84.49 \\
\hline 7 & $\begin{array}{l}\text { Memungkin pembelajaran } \\
\text { dilakukan murid berulang- ulang }\end{array}$ & 100 & 69.44 & 110 & 74.32 \\
\hline 8 & $\begin{array}{l}\text { Mengupayakan pendekatan } \\
\text { individual dalam pembelajaran }\end{array}$ & 131 & 90.97 & 140 & 94.60 \\
\hline 9 & $\begin{array}{l}\text { Mengupayakan pengakhiran } \\
\text { pembelajaran sesuai dengan } \\
\text { kemampuan murid }\end{array}$ & 108 & 75 & 131 & 88.51 \\
\hline 10 & $\begin{array}{l}\text { Guru siap membantu murid yang } \\
\text { bermasalah }\end{array}$ & 111 & 77.08 & 126 & 85.14 \\
\hline 11 & $\begin{array}{l}\text { Berusaha membantu kepribadian } \\
\text { murid dengan sabar }\end{array}$ & 138 & 95.83 & 144 & 97.30 \\
\hline 12 & $\begin{array}{l}\text { Menyingkirkan kegiatan yang } \\
\text { akan membahayakan murid }\end{array}$ & 125 & 86.80 & 133 & 89.86 \\
\hline 13 & $\begin{array}{l}\text { Membina hubungan dan } \\
\text { komunikasi yang positif }\end{array}$ & 119 & 82.64 & 134 & 90.54 \\
\hline 14 & $\begin{array}{l}\text { Memberikan hukuman yang } \\
\text { mendidik terhadap murid yang } \\
\text { bersalah }\end{array}$ & 83 & 57.64 & 92 & 62.16 \\
\hline 15 & $\begin{array}{l}\text { Menyediakan bahan bacaan yang } \\
\text { bervariasi }\end{array}$ & 87 & 60.42 & 115 & 77.70 \\
\hline 16 & $\begin{array}{l}\text { Memberikan kesempatan murid } \\
\text { untuk berkembang }\end{array}$ & 124 & 86.11 & 137 & 92.57 \\
\hline 17 & $\begin{array}{l}\text { Menanamkan nilai-nilai } \\
\text { kehidupan dalam pembelajaran }\end{array}$ & 123 & 85.41 & 139 & 93.92 \\
\hline 18 & $\begin{array}{l}\text { Menanamkan rasa tanggung } \\
\text { jawab dalam pembelajaran }\end{array}$ & 120 & 83.33 & 137 & 92.57 \\
\hline 19 & $\begin{array}{l}\text { Menjadi pendengar yang baik } \\
\text { bagi murid }\end{array}$ & 132 & 91.66 & 140 & 94.60 \\
\hline \multirow[t]{2}{*}{20} & $\begin{array}{l}\text { Memberikan penguatan positif } \\
\text { terhadap perilaku positif yang } \\
\text { ditampilakn murid }\end{array}$ & 134 & 93.05 & 139 & 93.92 \\
\hline & Rata-rata & 115 & 79.86 & 129 & 87.16 \\
\hline
\end{tabular}

Terdapat peningkatan pemahaman mahasiswa tentang tugas perkembangan siswa sekolah dasar kelas rendah maupun kelas tinggi. Di kelas rendah peningkatan dari sebelum dilaksanakan tutorial dengan setelah dilaksanakan tutorial dengan hasil perhitungan persentasenya 71,29\% menjadi $81,71 \%$. Di kelas tinggi dari sebelum dilaksanakan kegiatan tutorial kepada setelah dilaksanakan tutorial dengan hasil perhitungan persentasenya $79,86 \%$ menjadi $87,16 \%$. Peningkatan yang tertinggi tentang pemahaman perkem-bangan emosi siswa sekolah dasar kelas rendah dari 81,94\% ke 84,02\%. Sedangkan peningkatan yang tertinggi di kelas tinggi tentang pelibatan siswa dalam kegiatan dari $65,97 \%$ menjadi $84,46 \%$.

Tabel 3. Langkah-langkah Diagnostik Kesulitan Belajar

\begin{tabular}{llcccc}
\hline No & \multicolumn{1}{c}{ Item } & $\begin{array}{c}\text { Skor sebelum } \\
\text { kegiatan tutorial }\end{array}$ & $\%$ & $\begin{array}{c}\text { Skor setelah } \\
\text { kegiatan tutorial }\end{array}$ & $\%$ \\
\hline 1 & $\begin{array}{l}\text { Mengidentifikasi murid yang } \\
\text { mengalami kesulitan }\end{array}$ & 123 & 85.41 & 141 & 95.27 \\
\hline $\begin{array}{l}\text { Melokalisasi letak kesulitan } \\
\text { belajar murid }\end{array}$ & 111 & 77.08 & 133 & 89.86 \\
\hline
\end{tabular}




\begin{tabular}{llcccc}
\hline 3 & Melokalisasi factor penyebab & 116 & 80.55 & 134 & 90.54 \\
& kesulitan balajar murid & & & \\
4 & Penetapan kemungkinan bantuan & 108 & 75 & 133 & 89.86 \\
5 & Melaksanakan bantuan & 117 & 81.25 & 134 & 90.54 \\
& Rata-rata & 115 & 79.86 & 135 & 91.21 \\
\hline
\end{tabular}

Terdapat peningkatan keterampilan mahasiswa tentang mengidentifikasi langkah-langkah diagnostik kesulitan belajar dari sebelum dilaksanakan tutorial sampai setelah dilaksanakan tutorial dengan hasil perhitungan prosentasenya dari 79,86\% menjadi 91,21\%. Peningkatan tertinggi pada penetapan kemungkinan bantuan dengan hasil perhitungan persentasenya dari $75 \%$ menjadi 89,86\%.

Tabel 4. Mengidentifikasi kesulitan belajar

\begin{tabular}{llcccc}
\hline No & \multicolumn{1}{c}{ Item } & $\begin{array}{c}\text { Skor sebelum } \\
\text { kegiatan tutorial }\end{array}$ & $\%$ & $\begin{array}{c}\text { Skor setelah } \\
\text { kegiatan tutorial }\end{array}$ & $\%$ \\
\hline 1 & Melihat hasil belajar murid & 133 & 92.36 & 141 & 95.27 \\
2 & $\begin{array}{l}\text { Membandingkan hasil belajar } \\
\text { murid dengan kelompok kelas }\end{array}$ & 118 & 81.94 & 135 & 91.22 \\
3 & Melihat tipe kesalahan murid & 107 & 74.30 & 120 & 81.08 \\
4 & Melihat kebiasaan belajar murid & 121 & 84.03 & 136 & 91.89 \\
& Rata-rata & 119.75 & 83.16 & 133 & 89.86 \\
\hline
\end{tabular}

Terdapat peningkatan keterampilan mahasiswa dalam mengidentifikasi kesulitan belajar siswa dari sebelum dilaksanakan tutorial dengan setelah dilaksanakan tutorial dengan hasil perhitungan persentasenya dari 83,16 \% menjadi 89,86 \%. Peningkatan keterampilan mahasiswa dalam mengidentifikasi kesulitan belajar siswa yang tertinggi pada melihat kebiasaan belajar murid dengan hasil perhitungan persentasenya dari $84,03 \%$ menjadi $91,89 \%$.

Tabel 5. Melokalisasi Letak Kesulitan Belajar Murid

\begin{tabular}{|c|c|c|c|c|c|}
\hline $\mathrm{No}$ & Item & $\begin{array}{c}\text { Skor sebelum } \\
\text { kegiatan tutorial }\end{array}$ & $\%$ & $\begin{array}{c}\text { Skor setelah } \\
\text { kegiatan tutorial }\end{array}$ & $\%$ \\
\hline 1 & $\begin{array}{l}\text { Meneliti mata pelajaran } \\
\text { yang menjadi kesulitan }\end{array}$ & 126 & 87.5 & 129 & 87.16 \\
\hline 2 & $\begin{array}{l}\text { Kawasan tujuan yang } \\
\text { belum dicapai }\end{array}$ & 113 & 78.47 & 119 & 80.41 \\
\hline \multirow[t]{2}{*}{3} & $\begin{array}{l}\text { Ruang lingkup materi } \\
\text { yang belum dikuasai }\end{array}$ & 115 & 79.86 & 122 & 82.43 \\
\hline & Rata-rata & 118 & 81.9 & 123.3 & 83.33 \\
\hline
\end{tabular}

Terdapat peningkatan keterampilan mahasiswa dalam mengidentifikasi letak kesulitan belajar siswa dari sebelum kegiatan tutorial sampai setelah diberi-kan tutorial dengan hasil perhitungan persentasenya dari 81,9 $\%$ menjadi $83,33 \%$. Peningkatan yang tertinggi pada ruang lingkup yang belum dikuasai murid dari $79.86 \%$ menjadi $82.43 \%$.

Tabel 6. Melokalisasi Faktor Penyebab Kesulitan Belajar Faktor Internal

\begin{tabular}{llcccc}
\hline No & \multicolumn{1}{c}{ Item } & $\begin{array}{c}\text { Skor sebelum } \\
\text { kegiatan tutorial }\end{array}$ & $\%$ & $\begin{array}{c}\text { Skor setelah } \\
\text { kegiatan tutorial }\end{array}$ & $\%$ \\
\hline 1 & Kemampuan & 116 & 80.55 & 132 & 89.19 \\
2 & Bakat & 96 & 66.66 & 122 & 82.43 \\
3 & Kecacatan fisik & 92 & 63.88 & 111 & 75 \\
4 & Gangguan emosi & 109 & 75.69 & 125 & 84.46 \\
5 & Sikap dan kebiasaan yang & 122 & 84.72 & 133 & 89.86 \\
& salah & & & 121 & 81.75 \\
\hline
\end{tabular}




\begin{tabular}{lllll}
\hline dalam belajar & & & & \\
Rata-rata & 105.83 & 73.50 & 124 & 83.78 \\
\hline
\end{tabular}

Tabel 7. Melokalisasi Faktor Penyebab Kesulitan Belajar Faktor Ekternal

\begin{tabular}{llcccc}
\hline No & \multicolumn{1}{c}{ Item } & $\begin{array}{c}\text { Skor sebelum } \\
\text { kegiatan tutorial }\end{array}$ & $\%$ & $\begin{array}{c}\text { Skor setelah } \\
\text { kegiatan tutorial }\end{array}$ & $\%$ \\
\hline 1 & $\begin{array}{l}\text { Kurikulum kurang fleksibel } \\
2\end{array}$ & 82 & 56.94 & 108 & 72.97 \\
& $\begin{array}{l}\text { Tugas /laporan terlalu } \\
\text { banyak }\end{array}$ & 105 & 72.92 & 117 & 79.05 \\
3 & $\begin{array}{l}\text { Metode mengajar kurang } \\
\text { bervariasi }\end{array}$ & 116 & 80.55 & 133 & 89.86 \\
4 & $\begin{array}{l}\text { Kurangnya sumber dan alat } \\
\text { belajar }\end{array}$ & 103 & 71.53 & 127 & 85.81 \\
Rata-rata & 101.5 & 70.47 & 121.25 & 81.93 \\
\hline
\end{tabular}

Terdapat peningkatan keterampilan mahasiswa dalam melokalisasi faktor penyebab kesulitan belajar dari factor internal dengan perhitungan persentasenya dari 73,50\% menjadi 83,78 \% maupun faktor ekternal dari $70,47 \%$ menjadi $81,83 \%$. Peningkatan tertinggi pada faktor internal yaitu faktor bakat dari $66.66 \%$ menjadi $82.43 \%$, dan faktor ekternal kurang fleksibelnya kurikulum dari $56.94 \%$ menjadi $72.97 \%$.

Tabel 8. Memperkirakan Bantuan

\begin{tabular}{llcccc}
\hline No & \multicolumn{1}{c}{ Item } & $\begin{array}{c}\text { Skor sebelum } \\
\text { kegiatan tutorial }\end{array}$ & $\%$ & $\begin{array}{c}\text { Skor setelah } \\
\text { kegiatan tutorial }\end{array}$ & $\%$ \\
\hline 1 & $\begin{array}{l}\text { Masih mungkinkah untuk } \\
\text { dibantu }\end{array}$ & 126 & 87.5 & 137 & 92.57 \\
2 & $\begin{array}{l}\text { Berapa lama waktu untuk } \\
\text { membantu }\end{array}$ & 114 & 79.16 & 134 & 90.54 \\
3 & $\begin{array}{l}\text { Di mana tempat membantu } \\
\text { Adakah orang lain yang akan }\end{array}$ & 116 & 84.72 & 136 & 91.90 \\
& $\begin{array}{l}\text { dilibatkan } \\
\text { Bagaimana cara membantu }\end{array}$ & 117 & 80.55 & 138 & 93.24 \\
Rata-rata & 119 & 81.25 & 135 & 91.22 \\
\hline
\end{tabular}

Terdapat peningkatan keterampilan mahasiswa dalam memperkirakan bantuan untuk murid sekolah dasar yang mengalami kesulitan dengan hasil perhitungan dari 82,63\% menjadi 91,90\%. Peningkatan yang tertinggi pada pelibatan orang lain dalam memperkirakan bantuan terhadap murid dari $80,55 \%$ menjadi $93,24 \%$.

Tabel 9. Penetapan Bantuan

\begin{tabular}{llcccc}
\hline No & \multicolumn{1}{c}{ Item } & $\begin{array}{c}\text { Skor sebelum } \\
\text { kegiatan tutorial }\end{array}$ & $\%$ & $\begin{array}{c}\text { Skor setelah } \\
\text { kegiatan tutorial }\end{array}$ & $\%$ \\
\hline 1 & $\begin{array}{l}\text { Memvariasikan metodologi } \\
\text { pengajaran }\end{array}$ & 111 & 77.08 & 122 & 82.43 \\
2 & $\begin{array}{l}\text { Menjaga agar tidak terulang } \\
\text { kesulitan yang sama }\end{array}$ & 112 & 77.77 & 131 & 88.51 \\
3 & $\begin{array}{l}\text { Berusaha mengembangkan } \\
\text { kemampuan murid } \\
\text { Rata-rata }\end{array}$ & 115 & 79.46 & 134 & 90.55 \\
\hline
\end{tabular}

Terdapat peningkatan kemampuan mahasiswa dalam penetapan bantuan terhadap murid dengan perhitungan persentase dari 78,24 \% menjadi 87,16\%. Peningkatan tertinggi dalam berusaha mengembangkan kemampuan murid dari 79,46\% menjadi 90,55\%. 
Tabel 10. Menindak Lanjuti Bantuan

\begin{tabular}{|c|c|c|c|c|c|}
\hline No & Item & $\begin{array}{c}\text { Skor sebelum } \\
\text { kegiatan tutorial }\end{array}$ & $\%$ & $\begin{array}{c}\text { Skor setelah } \\
\text { kegiatan tutorial }\end{array}$ & $\%$ \\
\hline 1 & $\begin{array}{l}\text { Melaksanakan pengajaran } \\
\text { perbaikan }\end{array}$ & 124 & 86.11 & 136 & 91.89 \\
\hline \multirow[t]{2}{*}{2} & $\begin{array}{l}\text { Melaksanakan program } \\
\text { pengayaan }\end{array}$ & 116 & 80.55 & 125 & 84.46 \\
\hline & Rata-rata & 120 & 83.33 & 130.5 & 88.18 \\
\hline
\end{tabular}

Terdapat peningkatan keterampilan mahasiswa dalam menindak lanjuti bantuan terhadap murid yang mengalami kesulitan belajar dari hasil perhitungan persentase dari 83,33\% menjadi 88,18 \%. Peningkatan tertinggi terletak pada pelaksanaan pengajaran perbaikan dari $86,11 \%$ menjadi $84,46 \%$.

Tabel 11. Strategi pembelajaran Visual dengan Gambar

\begin{tabular}{|c|c|c|c|c|c|}
\hline No & Item & $\begin{array}{c}\text { Skor sebelum } \\
\text { kegiatan tutorial }\end{array}$ & $\%$ & $\begin{array}{c}\text { Skor setelah } \\
\text { kegiatan tutorial }\end{array}$ & $\%$ \\
\hline 1 & $\begin{array}{l}\text { Mengembangkan } \\
\text { keterampilan mengamati }\end{array}$ & 105 & 72.91 & 122 & 82.43 \\
\hline 2 & $\begin{array}{l}\text { Murid diarahkan untuk } \\
\text { terpusat pada vigur }\end{array}$ & 108 & 75 & 118 & 79.73 \\
\hline 3 & $\begin{array}{l}\text { Murid diarahkan untuk } \\
\text { mengamati secar keseluruhan }\end{array}$ & 105 & 72.91 & 123 & 83.11 \\
\hline 4 & $\begin{array}{l}\text { Murid diarahkan untuk } \\
\text { menggambarkan objek }\end{array}$ & 110 & 76.39 & 121 & 81.76 \\
\hline & Rata-rata & 107 & 74.30 & 121 & 81.76 \\
\hline
\end{tabular}

Tabel 12. Visual dengan Lukisan Verbal

\begin{tabular}{|c|c|c|c|c|c|}
\hline No & Item & $\begin{array}{c}\text { Skor sebelum } \\
\text { kegiatan tutorial }\end{array}$ & $\%$ & $\begin{array}{c}\text { Skor setelah } \\
\text { kegiatan tutorial }\end{array}$ & $\%$ \\
\hline 1 & $\begin{array}{l}\text { Mempertajam keterampilan } \\
\text { mengamati }\end{array}$ & 101 & 70.14 & 111 & 75 \\
\hline 2 & $\begin{array}{l}\text { Memperluas pengetahuan } \\
\text { murid }\end{array}$ & 112 & 77.77 & 125 & 84.46 \\
\hline \multirow[t]{2}{*}{3} & $\begin{array}{l}\text { Mengarahkan murid untuk } \\
\text { cermat mengamati }\end{array}$ & 106 & 73.61 & 120 & 81.08 \\
\hline & Rata-rata & 106 & 73.84 & 118.67 & 80.18 \\
\hline
\end{tabular}

Tabel 12. Visual dengan Kalimat Kunci

\begin{tabular}{lllllc}
\hline No & \multicolumn{1}{c}{ Item } & \multicolumn{1}{c}{$\begin{array}{c}\text { Skor sebelum } \\
\text { kegiatan tutorial }\end{array}$} & $\%$ & $\begin{array}{c}\text { Skor setelah } \\
\text { kegiatan tutorial }\end{array}$ & $\%$ \\
\hline 1 & Menyajikan kata-kata kunci & 101 & 70.14 & 118 & 79.73 \\
2 & $\begin{array}{l}\text { Menuliskan kata-kata di } \\
\text { papan tulis }\end{array}$ & 107 & 74.31 & 124 & 83.78 \\
3 & $\begin{array}{l}\text { Menganalisis katak-kata kunci } \\
4\end{array}$ & 96 & 66.66 & 117 & 79.05 \\
& Memakai kata-kata kunci & 97 & 67.36 & 121 & 81.76 \\
& untuk membentuk kalimat & 100.25 & 69.62 & 121 & 81.08 \\
\hline
\end{tabular}

Terdapat peningkatan keterampilan mahasiswa dalam melaksanakan strategi pembelajaran berupa pembelajaran dengan a) strategi visual bergambar dengan hasil perhitungan persentasenya dari 74,30 \% menjadi $81,76 \%$, b) strategi visual dengan lukisan verbal dengan hasil perhitungan persentasenya dari 73,84 $\%$ menjadi $80,18 \%$, c) visual dengan kalimat kunci dengan hasil perhitungan persentasenya dari 69,62\% 
menjadi $81,08 \%$. Peningkatan yang tertinggi pada a) strategi visual bergambar pada murid diarahkan untuk mengamati secara keseluruhan dari $72,39 \%$ menjadi $81,76 \%$, b) strategi visual lukisan verbal pada muridmurid diarahkan untuk cermat mengamati dari 73,61\% menjadi $81,08 \%$, c) stratergi visual dengan kalimat kunci pada memakai kata kunci untuk membentuk kalimat dari $67,36 \%$ menjadi $81,76 \%$.

Tabel 13. Usaha Guru untuk Meningkatkan Potensi Murid

\begin{tabular}{|c|c|c|c|c|c|}
\hline No & Item & $\begin{array}{c}\text { Skor sebelum } \\
\text { kegiatan tutorial }\end{array}$ & $\%$ & $\begin{array}{c}\text { Skor setelah } \\
\text { kegiatan tutorial }\end{array}$ & $\%$ \\
\hline 1 & $\begin{array}{l}\text { Membelajarkan murid dengan } \\
\text { strategi visual }\end{array}$ & 100 & 69.44 & 119 & 80.41 \\
\hline 2 & $\begin{array}{l}\text { Membelajarkan murid dengan } \\
\text { strategi grafis }\end{array}$ & 84 & 56.25 & 102 & 68.92 \\
\hline 3 & $\begin{array}{l}\text { Membelajarkan murid dengan } \\
\text { strategi fantasi }\end{array}$ & 96 & 66.66 & 113 & 76.35 \\
\hline 4 & $\begin{array}{l}\text { Membelajarkan murid dengan } \\
\text { strategi bahasa }\end{array}$ & 115 & 79.86 & 129 & \\
\hline 5 & $\begin{array}{l}\text { Membelajarkan murid dengan } \\
\text { strategi kiasan }\end{array}$ & 81 & 56.25 & 87.16 & \\
\hline 6 & $\begin{array}{l}\text { Membelajarkan murid dengan } \\
\text { strategi multisensori }\end{array}$ & 93 & 64.58 & 72.97 & \\
\hline \multirow[t]{2}{*}{7} & $\begin{array}{l}\text { Membelajarkan murid dengan } \\
\text { strategi pengayaan }\end{array}$ & 116 & 80.55 & 73.65 & 82.43 \\
\hline & Rata-rata & 97.86 & 67.95 & 114.57 & 77.41 \\
\hline
\end{tabular}

Terdapat peningkatan keterampilan mahasiswa dalam mengusahakan untuk meningkatkan potensi murid dengan hasil perhitungan persentasenya dari 67, 95\% menjadi 77,41\%. Peningkatan tertinggi pada membelajarkan murid dengan strategi kiasan dari 56,25\% menjadi 72,97\%.

Tabel 14. Rekapitulasi hasil keseluruhan hasil penelitian tindakan kelas (PTK) matakuliah diagnostik kesulitan belajar

\begin{tabular}{|c|c|c|c|c|c|}
\hline No & Item & $\begin{array}{l}\text { Rata } 2 \text { Skor Sebelum } \\
\text { Kegiatan tutorial }\end{array}$ & $\%$ & & $\begin{array}{c}\text { Rata } 2 \text { Skor Setelah } \\
\text { Kegiatan tutorial }\end{array}$ \\
\hline \multirow[t]{3}{*}{1} & $\begin{array}{l}\text { Pemahaman tentang tugas } \\
\text { perkembangan siswa }\end{array}$ & & & & \\
\hline & a. Kelas rendah & 102.66 & 71.29 & 117.67 & 81.71 \\
\hline & b. Kelas tinggi & 115 & 79.86 & 129 & 87.16 \\
\hline 2 & $\begin{array}{l}\text { Langkah-langkah diagnostic } \\
\text { kesulitan belajar }\end{array}$ & 115 & 79.86 & 135 & 91.22 \\
\hline 3 & Mengidentifikasi kesulitan belajar & 119.75 & 83.16 & 133 & 89.86 \\
\hline 4 & Melokalisasi kesulitan belajar & 118 & 81.9 & 123 & 83.33 \\
\hline \multirow[t]{3}{*}{5} & $\begin{array}{l}\text { Melokalisasi faktor penyebab } \\
\text { kesulitan belajar }\end{array}$ & & & & \\
\hline & a. Faktor internal & 105.83 & 73.50 & 124 & 83.78 \\
\hline & b. Faktor ekternal & 101.5 & 70.74 & 121.25 & 81.93 \\
\hline 6 & Memperkirakan bantuan & 119 & 82.63 & 136 & 91.90 \\
\hline 7 & Penetapan bantuan & 112,67 & 78.24 & 129 & 87.16 \\
\hline 8 & Menindak lanjuti bantuan & 120 & 83,33 & 130.5 & 88.18 \\
\hline \multirow[t]{4}{*}{9} & $\begin{array}{l}\text { Strategi pembelajara } \\
\text { a. Visual dengan gambar }\end{array}$ & & & & \\
\hline & b. Visual dengan lukisan verbal & 107 & 74.30 & 121 & 81.76 \\
\hline & c. Visual dengan kata kunci & 106 & 73.84 & 118.67 & 80.18 \\
\hline & & 100.25 & 69.62 & 121 & 81.08 \\
\hline 10 & $\begin{array}{l}\text { Usaha guru untuk meningkatkan } \\
\text { potensi murid }\end{array}$ & 97.86 & 67.95 & 114.57 & 77.41 \\
\hline
\end{tabular}




$\begin{array}{lllll}\text { Rata-rata } & 110.75 & 76.52 & 125.26 & 84.76\end{array}$

Terdapat peningkatan keterampilan mahasiswa dalam melaksanakan kegiatan diagnosis kesulitan belajar dari sebelum diberikan strategi pembelajaran tutorial kepada setelah diberikan pembelajaran tutorial hal ini tergambar dengan hasil perhitungan persentase dari sebelum 76,52\% menjadi 84,76\% setelah diberikan pembelajaran tutorial. Peningkatan tertinggi pada keterampilan mahasiswa melaksanakan langkah-langkah diagnostic kesulitan belajar dengan hasil perhitungan persentasenya sebelum pembelajaran tutorial 79,86\% mendjadi 91,22\% setelah pembelajaran tutorial.

\section{Pembahasan}

Apabila diteliti hasil PTK pada BAB IV secara keseluruhan terdapat peningkatan persentase skor sebelum kegiatan tutorial dan setelah kegiatan tutorial. Contoh Pemahaman mahasiswa tentang tugas perkembangan siswa sekolah dasar hal ini terjadi karena sebelum kegiatan tutorial dilaksanakan mahasiswa hanya mengandalkan pengetahuan mereka tentang psikologi perkembangan 1 yang dipelajari pada semester 3, sedangkan pelaksanaan mata kuliah diagnostik kesulitan belajar ini pada semester 6 , jadi mahasiswa mungkin sudah banyak yang lupa tentang materi psikologi perkembangan

Setelah dilaksanakan tutorial terjadi perubahan skor penguasaan mahasiswa, hal ini juga terjadi karena mahasiswa bekerja secara kelompok dikelas di bawah pengawasan dosen pengampu, dengan sendirinya terjadi komunikasi yang efektif diantara mahasiswa dan mereka saling mengingatkan. Di tambah lagi setelah mahasiswa melaksanakan tutorial di kelas mereka juga diharuskan dalam mata kuliah ini untuk mempraktekan atau melihat dan mengamati bagaimana perkembangan siswa sekolah dasar.

Dalam memahami langkah-langkah diagnostik kesulitan belajar sebelum kegiatan tutorial penguasaan mahasiswa masih rendah (hanya $75 \%$ ), sedangkan setelah kegiatan tutorial diadakan di kelas dan kegiatan praktek di sekolah latihan penguasaan mahasiswa meningkat hal ini terlihat dengan terjadinya perubahan nilai mahasiswa semuanya mendapat persentase tinggi (di atas 89\%). Hal ini terjadi karena dalam kegiatan tutorial mahasiswa saling berbagi pengetahuan tentang langkah-langkah diagnostik kesulitan belajar dan mereka melaksanakan sendiri di sekolah latihan, bila mahasiswa menemukan kesulitan dalam memahami dan melaksanakan langkah-langkah kesulitan belajar di sekolah latihan, mahasiswa langsung berdiskusi sesame mahasiswa bila belum teratasi mereka berkonsultasi dengan dosen pengampu.

Mahasiswa sebelum diadakan kegiatan tutorial diberikanan asesmen tentang mengidentifikasi kesulitan belajar, ternyata dalam penetapan kemungkinan bantuan yang berkaitan dengan melihat tipe kesalahan murid mahasiswa mendapat persentase yang rendah (hanya 74\%). Hal ini terjadi karena karena sebelum kegiatan tutorial dosen belum memberikan materi perkuliahan tentang mengidentifikasi kesulitan belajar. Mahasiswa diarahkan untuk mendiskusikan tentang mengidentifikasi kesulitan belajar di kelas. Selama mahasiswa berdiskusi dosen selalu memberikan arahan tentang cara-cara untuk mengidentifikasi kesulitan belajar, sehingga setelah diadakan tutorial terdapat peningkatan persentase penguasaan mahasiswa (81\%).

Dalam melokalisasi letak kesulitan belajar murid, penguasaan mahasiswa juga rendah terutama yang berkenaan dengan kawasan tujuan yang belum di capai dan ruang lingkup materi yang belum di kuasai (78\% dan 79\%), hal ini terjadi karena materi perkuliahan kurikulum didapat mahasiswa pada semester 4, dan materi kuliah kurikulum tidak dikuhususkan pada materi kurikulum sekolah dasar, sedangkan dalam mata kuliah diagnostic kesulitan belajar mahasiswa di fokuskan pada kurikulum sekolah dasar, dengan sendirinya penguasaan mahasiswa belum memadai. Sedangkan setelah kegiatan tutorial mahasiswa diarahkan untuk mempokuskan diri pada kurikulum sekolah dasar dan mereka diharus untuk memahami kurikulum di kelas di mana mereka praktek, hal ini tentu membawa efek pada penguasaan mahasiswa karena mereka langsung diarahkan dan mempraktekkannya di kelas sekolah latihan sehingga penguasaan mahasiswa meningkat (di atas $80 \%$ ).

Melokalisasi faktor penyebab kesulitan belajar merupakan kesulitan tersendiri bagi mahasiswa sebelum dilaksanakan tutorial, hal ini tergambar dengan persentase penguasaan mahasiswa yang meliputi faktor internal dan ekternal. Penguasaan mahasiswa dalam melokasilsasi faktor internal lebih rendah dari faktor ekternal. Hal ini terjadi karena dalam keseluruhan materi perkuliahan di jurusan Bimbingan dan konseling FIP UNP tidak ada mengkhususkan pembahasan materi kearah penyebab kesulitan belajar di sekolah dasar. Setelah tutorial dilaksanakan dan pengarahan dari dosen pengampu terjadi perubahan peningkatan penguasaan 
mahasiswa tentang faktor penyebab kesulitan belajar ini, hal ini terjadi karena selama kegiatan tutorial mahasiswa saling berkomunikasi dan menyampaikan hasil pengamatan mereka yang ditemui di lapangan dan dosen pengampu selalu memberikan arahan sehingga kesulitan mahasiswa dapat di atasi.

Memperkirakan bantuan terhadap siswa yang bermasalah, terjadi juga peningkatan sebelum diadakan kegiatan tutorial dengan sesudah diadakan tutorial (sebelum 81. $63 \%$ sesudah $91.90 \%$ ), hal ini disebabkan karena masing-masing mahasiswa mempelajari tugas perkembangan siswa yang di pelajari di kelas, kemudian mahasiswa harus mengamati ketercapaian tugas perkembangan siswa baik di sekolah maupun di rumah, dan mereka diharuskan untuk mewawancarai orang tua atau orang tua asuh yang bertanggung jawab terhadap pendidikan siswa di rumah. Jika mahasiswa menemukan kesulitan dapat berkonsultasi langsung dengan dosen pengampu baik pada jam kuliah maupun di luar jam kuliah.

Penetapan bantuan merupakan usaha yang akan dilakukan mahasiswa untuk membantu siswa yang mengalami kesulitan belajar. Dengan adanya penetapan bantuan akan ada kesepakatan antara guru dan siswa dalam melaksanakan kegiatan pemberian bantuan hal ini terlihat dari hasil yang didapat terjadi peningkatan penetapan bantuan sebelu diadakan tutorial penguasaan mahasiswa hanya $78.24 \%$, sedangkan setelah diberikan tutorial penguasaan mahasiswa menjadi $87.16 \%$, hal ini terjadi karena mahasiswa belajar secara kelompok dan dilayani oleh dosen kesulitan mahasiswa sesuai dengan kesulitan yang dihadapinya di kelompok belajar.

Menindak lanjuti bantuan juga terjadi peningkatan yaitu dari $83.33 \%$ menjadi $88.18 \%$, walaupun angka kenaikannya idak mencolok, namun karena mereka dilayani sesuai dengan kegiatan mereka sehingga mahasiswa dapat memikirkan tindak lanjut dari penguasaan yang diperoleh.

\section{SIMPULAN DAN SARAN}

Secara umum kemampuan mahasiswa dalam memahami perkuliahan diagnostik kesulitan belajar melalui pengajaran tutorial meningkat hal ini dapat dilihat dari skor penilaian yang diberikan sebelum pengajaran tutorial dengan sesudah pengajaran tutorial secara rinci dapat disimpulkan bahwa (1) Terdapat peningkatan kemampuan awal mahasiswa setelah mengikuti perkuliahan pembelajaran tutorial dalam mata kuliah diagnosis kesulitan belajar dalam mengamati tugas perkembangan murid sekolah dasar, (2) Terdapat peningkatan keterampilan mahasiswa dalam melaksanakan langkah-langkah diagnostik kesulitan belajar melalui pengajaran tutorial, (3) Terdapat peningkatan keterampilan mahasiswadalam mengidentifikasi kesulitan belajar siswa melalui pengajaran tutorial, (4) Terdapat peningkatan keterampilan mahasiswa mengalokasikan letak kesulitan belajar siswa melalui pengajaran tutorial, (5) Terdapat peningkatan keterampilan mahasiswa dalam melokasisasi faktor kesulitan belajar melalui pengajaran tutorial, (5) Terdapat peningkatan keterampilan mahasiswa dalam memperkirakan bantuan melalui pengajaran turorial, (6) Terdapat peningkatan keterampilan mahasiswa menetapkan bantuan melalui pengajaran tutorial, (7) Terdapat peningkatan keterampilan mahasiswa dalam melaksanakan tindak lanjut melalui pengajaran tutorial, dan (8) Terdapat peningkatan keterampilan mahasiswa untuk mengusahakan peningkatan potensi siswa yang mengalami kesulitan belajar melalui pengajaran tutorial.

Berdasarkan simpulan tersebut maka saran yang dapat diberikan apabila dosen akan melaksanakan PTK tutorial sebaiknya dosen bersama team serentak masuk kelas, akan tetapi dalam pelaksanaan PTK tutorial ini dosen pengampu hanya melaksanakan sendiri karena team pengajar diagnostik kesulitan belajar juga mengajar pada jam yang sama. Diharapkan jumlah kelas dibatasi hanya 30 orang saja, sehingga keintensifan tutorial akan lebih efektif.

\section{DAFTAR RUJUKAN}

Agus Salim. (2004). Indonesia Belajarlah Senang. Indonesia: Gerbang Madani.

Anggina Pratiwi Haryatni. (2014). "Identifikasi faktor-faktor penyebab kesulitan belajar pada siswa SMP Negeri 5 kota Jambi." Skripsitidak diterbitkan. Jambi: FKIP Universitas Jambi. 
Nana Sujana. (1991). Penelitian Deskriptif. Bandung: Remaja Karya.

Ni Putu Sri Nonik Andayani, dkk. (2014). "Penerapan layanan bimbingan belajar untuk meningkatkan prestasi belajar bagi siswa yang mengalami kesulitan belajar siswa kelas X4 SMA Negeri 1 Sukasada." Jurnaltidak diterbitkan. Singaraja: Universitas Pendidikan Ganesha.

Nurhijrah, G dan Hadiyanto. (2001). "Peningkatan Kualitas Melalui Profesionalisme Guru serta Implementasi Manajemen Berbasis Sekolah". Artikel tidak diterbitkan. Padang:Pasca Sarjana.

Prayitno, dkk. (1997). Seri Pemandu Pelayanan Bimingan dan Konseling di sekolah. Jakarta:Penebar Aksara.

Rochman Natawijaya dan Moein Moesa. (1992). Psikologi Pendidikan.Jakarta: Departemen Pendidikan dan kebidayaan.

Sarlito Wirawan. (2008). Psikologi Remaja. Jakarta: Raja Grafindo.

Suaharsimi.( 2006). Prosedur Penelitian Suatu Pendekatan Praktek. Jakarta:Rineka Cipta.

Sukirman. (2011). Penelitian Tindakan Kelas untuk Guru Pembimbing (Bimbingan dan Konseling). Yogyakarta: Paramitra Publishing.

Sumadi Sujabrata. (1984). Psikologi Belajar. Jogjakarta:UGM.

Woolfolk, Anita. (2008). Educational Psychology, Active Learning Edition. Terjemahan oleh Helly Prajitno Soetjipto dan Sri Mulyantini Soetjipto. Yogyakarta: Pustaka Pelajar.

Zaenal Abidin. (2006). "Layanan bimbingan belajar sebagai upaya peningkatan kualitas proses belajar mengajar." Jurnal tidak diterbitkan. Purwokerto: P3M STAIN Purwokerto.

Ahmad, A., Al-mashari, A., \& Al-lawati, A. (2010). On the development of a computer based diagnostic assessment tool to help in teaching and learning process, 6(1), 76-87.

Bear, A. A. G. (2012). Technology, Learning, and Individual Differences, 41(2), 43-44.

Khiat, H. (2015). Measuring Self-Directed Learning: A Diagnostic Tool for Adult Learners Measuring SelfDirected Learning: A Diagnostic Tool for Adult Learners, 12(2). 